\title{
Agricultural Decline, Landscape Change, and Outmigration
}

Author(s): Reto Soliva

Source: Mountain Research and Development, 27(2):124-129.

Published By: International Mountain Society

DOI: http://dx.doi.org/10.1659/mrd.0907

URL: http://www.bioone.org/doi/full/10.1659/mrd.0907

BioOne (www.bioone.org) is a nonprofit, online aggregation of core research in the biological, ecological, and environmental sciences. BioOne provides a sustainable online platform for over 170 journals and books published by nonprofit societies, associations, museums, institutions, and presses.

Your use of this PDF, the BioOne Web site, and all posted and associated content indicates your acceptance of BioOne's Terms of Use, available at www.bioone.org/page/terms_of_use.

Usage of BioOne content is strictly limited to personal, educational, and non-commercial use. Commercial inquiries or rights and permissions requests should be directed to the individual publisher as copyright holder. 


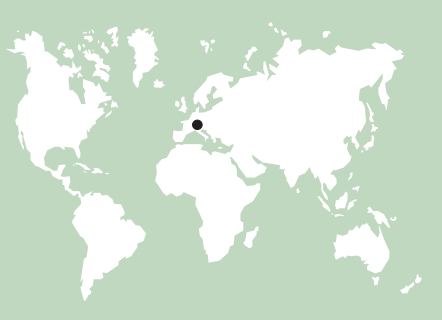

As in many other mountain areas, peripheral regions of the Swiss Alps are experiencing outmigration, especially of younger people, due to lack of opportunities. Winter tourism, often the backbone of regional economies, is declining in many small- and mediumsized resorts. At the same time, agricultural decline is leading to land abandonment and natural reforestation, which may have implications for the sustainability of development in these areas. In a case study of the European Union (EU) BioScene research project, 3 agricultural and land use scenar- ios were developed for the Surses valley in the Canton of Grisons and assessed with respect to their sustainability implications, including discussions with a local stakeholder group. In mitigating outmigration from this peripheral area, it is important that local people can identify with the development taking place in their region, and with the landscape in which they live. Based on the discussion of the scenarios with local stakeholders and the sustainability assessment, it was possible to formulate policy recommendations.

\section{"Visitors from the cities} don't live here, but we do (...). We won't allow the centers to subjugate us.

Rather, we are the counterpole of the centers. It will never be the centers that prescribe what we implement here. We are not establishing this regional park just to do the centers a favor; we do this on our own initiative. Not as a servant of a center. (...) We want to keep our independence, and that rewilding stuff, we already have enough of that." (Inhabitant of the Surses valley, Canton of Grisons, Switzerland)

\section{The threatened viability of peripheral areas}

The quote from an inhabitant of the Surses valley in the Swiss Canton of Grisons (see left) vividly illustrates the desire of local people to remain in this peripheral mountain area, and the determination with which they defend their autonomy in maintaining the cultural landscape they want. The region faces an uncertain future: winter tourism, the backbone of the economy in this medium-sized ski resort, has been declining over the last two decades, and many young people leave the area due to lack of opportunities. While the number of inhabitants in larger, well-connected villages has remained stable or is even increasing, the viability of smaller communities is threatened by continuing outmigration.

Most of the productive land in the Surses has traditionally been used for agriculture, which is largely based on dairy production and involves summering cattle on alpine pastures and cut meadows for fodder production for the winter. However, structural changes in agriculture have led to a decline in agricultural land use in recent decades. The number of farms continues to decrease, and while the remaining farms increase in size, much "marginal" land that is not easily accessible or too steep to be mown by machinery is being abandoned. As a consequence, these areas are invaded by shrubs and bushes, and finally become spruce forest. Between 1985 and 1997, the forest area in the Surses increased by $8 \%$ and the effects of natural reforestation on the landscape are becoming apparent.
It should be pointed out that in an international context-even within Europe-agriculture in Switzerland has been, and still is, heavily protected, and there has been relatively little structural change. Also, peripheral areas have been heavily supported in order to ensure decentralized settlement. However, things are changing: most market subsidies for agricultural products have already been replaced by direct payments given to farmers for their provision of public goods and services-for instance, landscape and biodiversity protection, and environmentally-friendly production.

Regarding regional policy, it is now openly discussed whether the state should withdraw all support to the most remote valleys with low development potential and let them become "alpine fallow land." This is mostly due to the need of the state to institute savings, but there is also a decreasing willingness among the public to support very remote areas. Moreover, recent studies have shown that many urban citizens in particular would like to have more wilderness areas in Switzerland, and favor the establishment of alpine protected areas that are left to themselves or only used in a low-key, sustainable way.

The Surses is not among the most peripheral areas, as it is easily accessible by a major road (Figure 1). However, recent trends raise important questions regarding the sustainability of development in this region: how will the gradual and irreversible loss of cultural landscapes affect tourism? And how will it affect the emotional attachment of local people to their region? If local people no longer feel at home in their landscape, they are less like- 
ly to care about sustainable development of their region. Finally, are these processes leading to economic decline and outmigration, or are there new chances and alternative development paths?

\section{Scenarios for the Surses in the year 2030}

In the Eu BioScene research project ("Scenarios for reconciling biodiversity conservation with declining agricultural use in the mountains of Europe"), 3 scenarios were developed for the Surses in the year 2030 and discussed with a local stakeholder group. Scenario technique is increasingly used in research and planning as a modeling instrument. Scenarios as "imaginative pictures of potential futures" facilitate dealing with uncertainty and complexity and encourage people to go beyond conventional ways of understanding an issue.

The BioScene scenarios focused on the impacts of changes in agricultural and conservation policies on the landscape and biodiversity. In a final phase of the project, however, the wider sustainability implications of the scenarios (including the aspects of biodiversity, natural resource management, rural development, social development, economic development, and institutional capacity) were examined. Throughout the project, researchers worked with a group of 12 local stakeholders who were selected to represent a maximum diversity of views, rather than particular institutions or organizations. All stakeholders were interviewed, and 3 group meetings were organized. Sustainability issues were discussed in the third meeting. The research process in this part of the project followed the principles of Sustainability Assessment (SA), a methodological framework increasingly used in planning and policy development. SA applies a set of procedures and techniques for assessing the social, economic, and environmental implications of projects, programs, and policies in an integrated manner. Using SA to assess scenarios is, however, a new application.

The 3 scenarios can be summarized as follows:

1. Business as Usual (BAU): it is assumed that current trends will continue; agri-

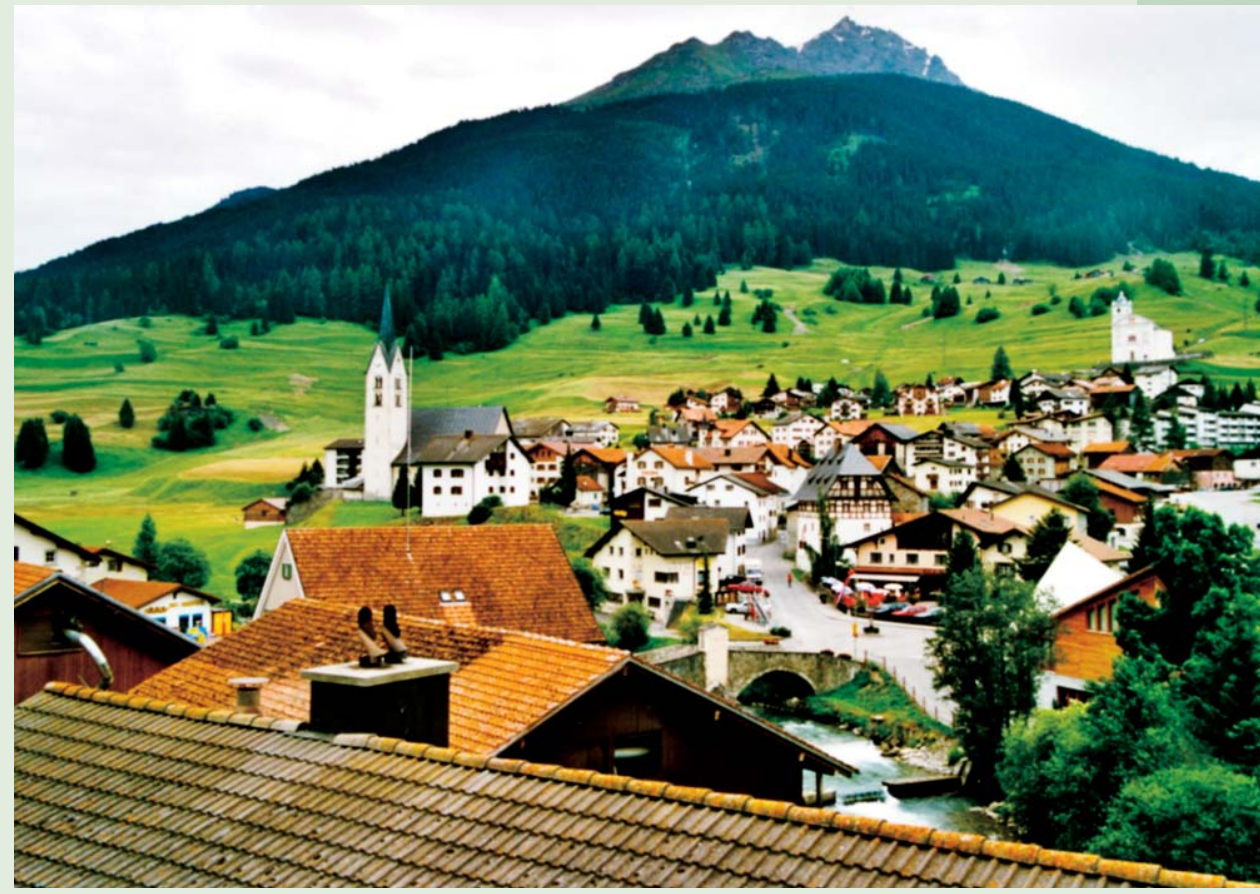

cultural support is maintained and structural change in agriculture continues at the current rate, leading to the abandonment of marginal land.

2. Agricultural Liberalization (LIB): it is assumed that financial support to both agriculture and conservation is canceled. Agricultural markets are completely liberalized and environmental regulations in agriculture are abolished. Consequently, most farms in the Surses are given up, and most of the land is left unused and eventually turns into forest.

3. Biodiversity Enhancement ( $\mathrm{BIO})$ : it is assumed that all support for agricultural production is replaced by biodiversity payments. The main aim of mountain agriculture is to promote the biodiversity of open land. The landscape is more structured, with smaller units, and part of the land is managed by conservation organizations.

The likely landscape consequences of the scenarios, as imagined by the researchers, were visualized with photo manipulations (Figures 2-5). The landscape visualizations were then rated by the stakeholders, independently of the associated scenarios. 
FIGURES 2-5: Examples of photo manipulations illustrating possible landscape changes at an alpine pasture in the Surses under the 3 scenarios. (Photo editing by Stefan Zantop)

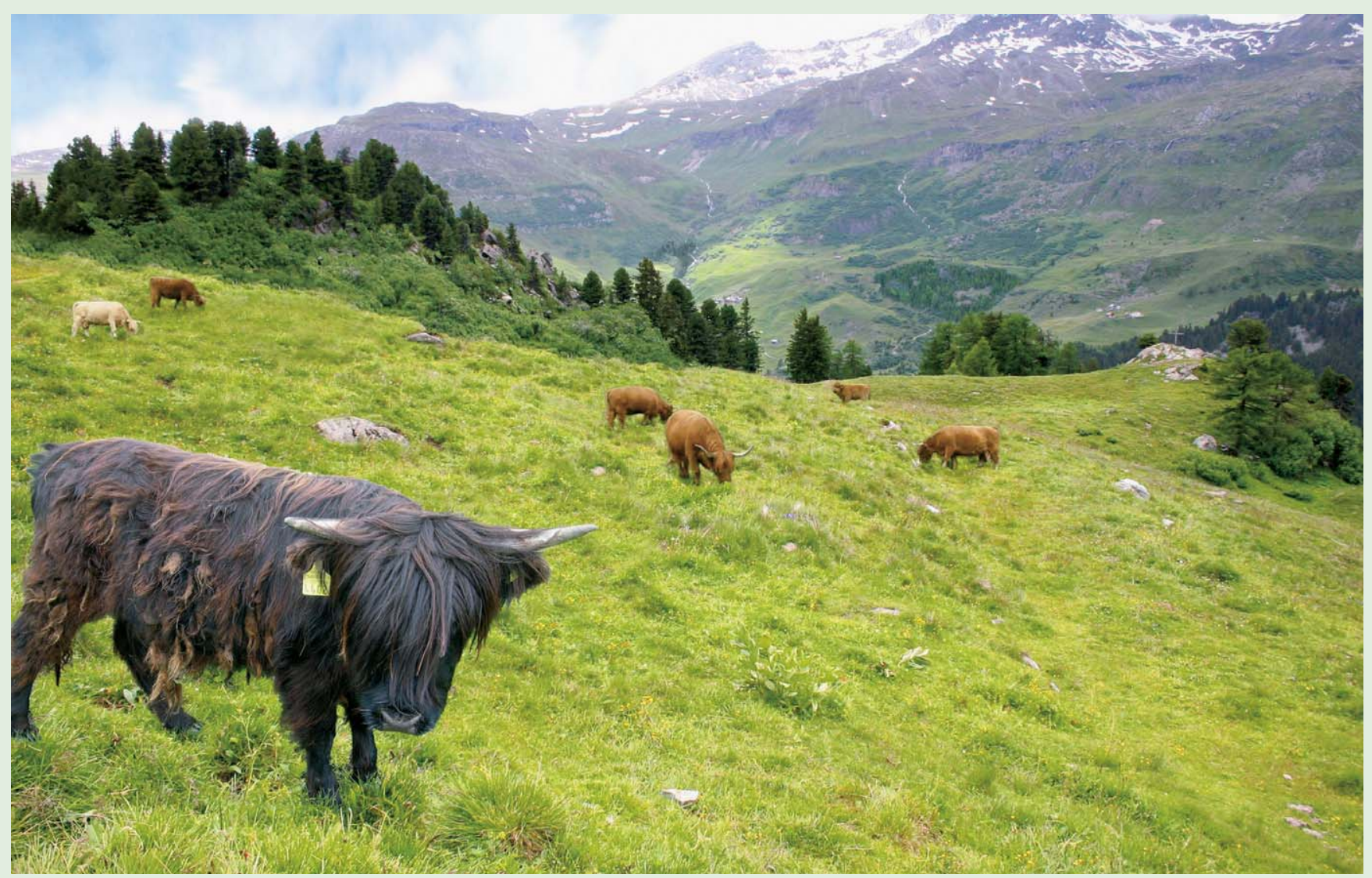

FIGURE 2 Business as Usual with (untypical) Scottish Highland cattle, illustrating a trend towards niche production.

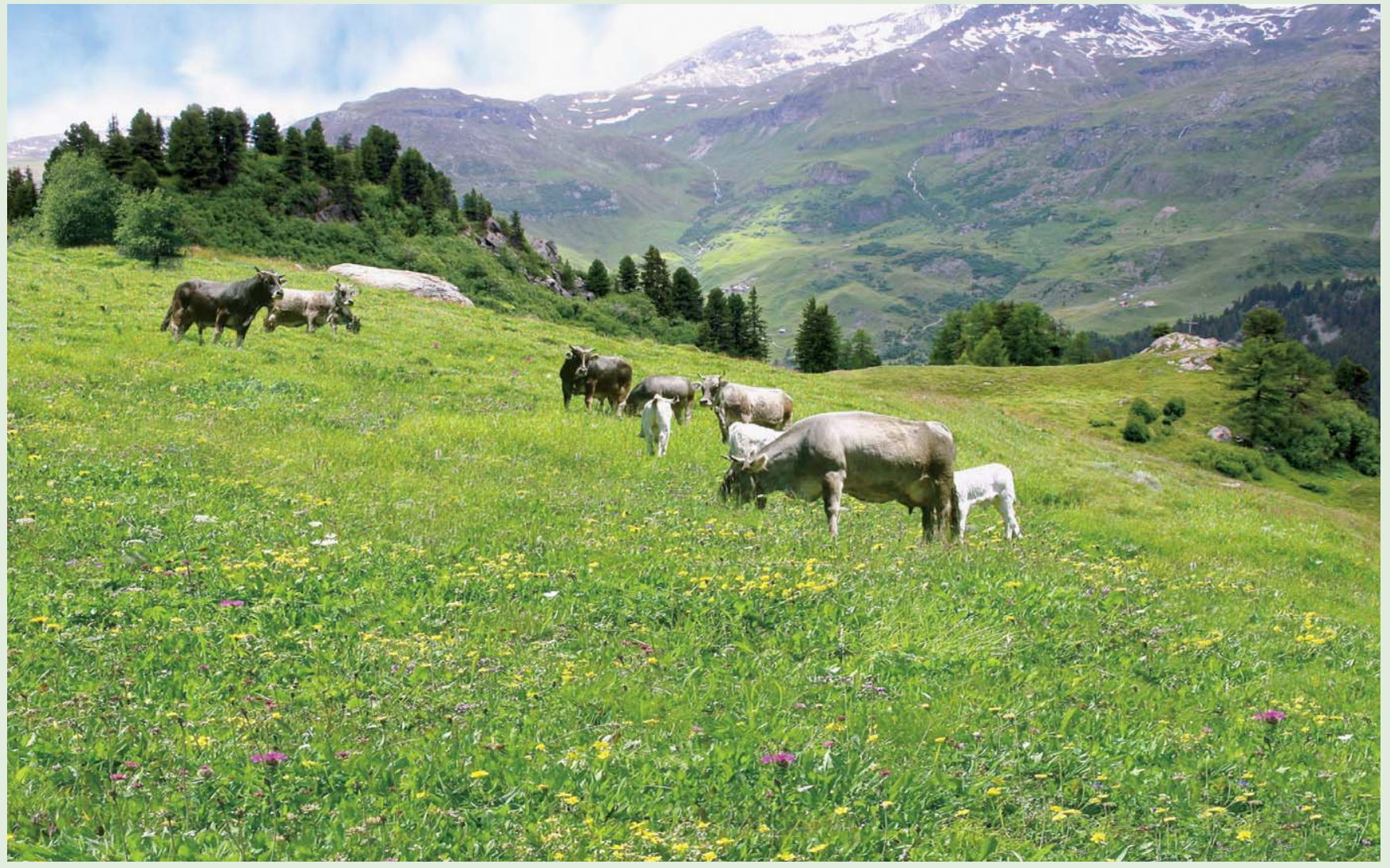

FIGURE 3 Biodiversity Enhancement with Rhaetian Grey cattle (a traditional local breed) and a high diversity of herbs and flowers. 


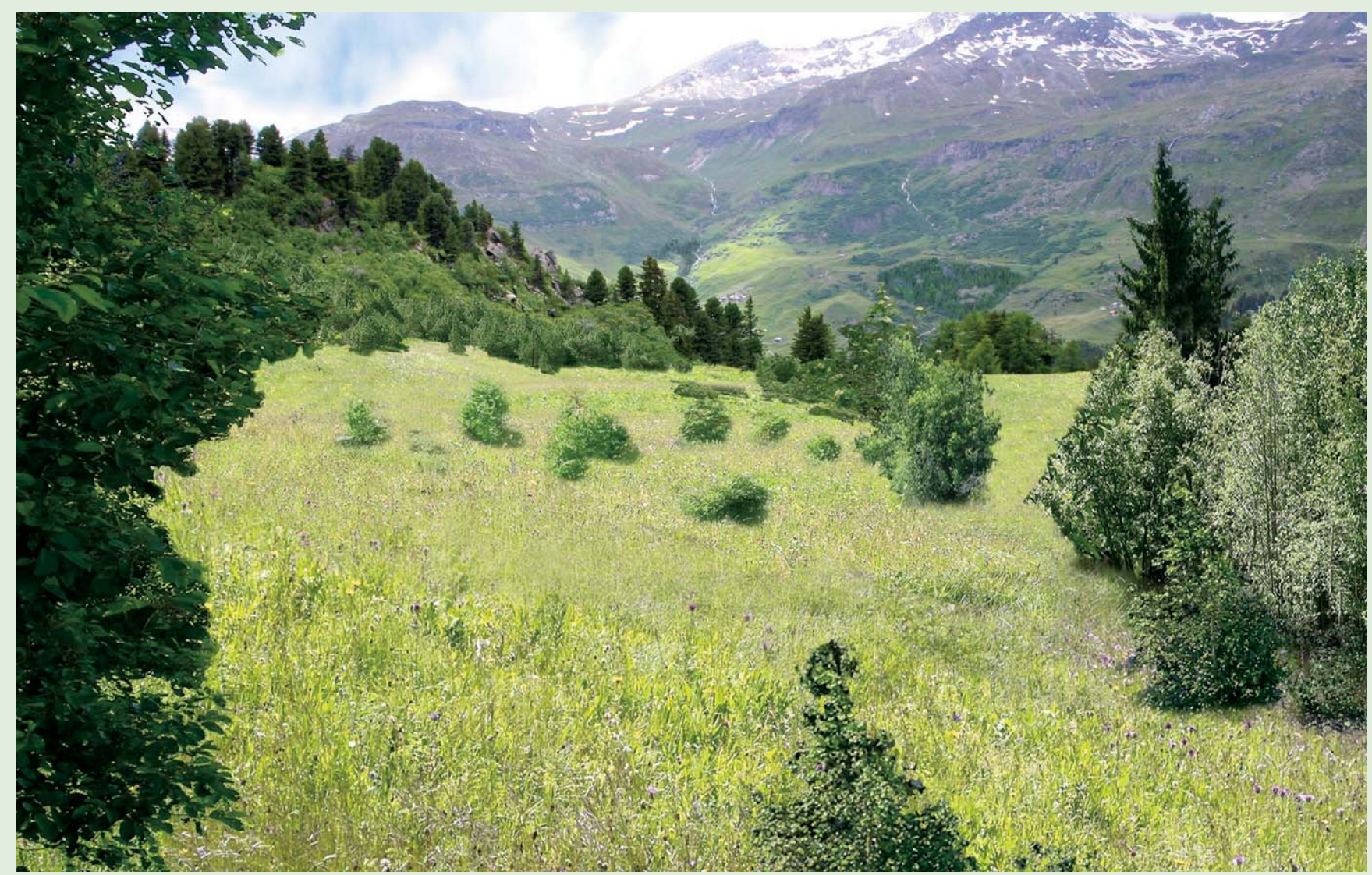

FIGURE 4 Agricultural Liberalization showing an early stage of vegetational succession.

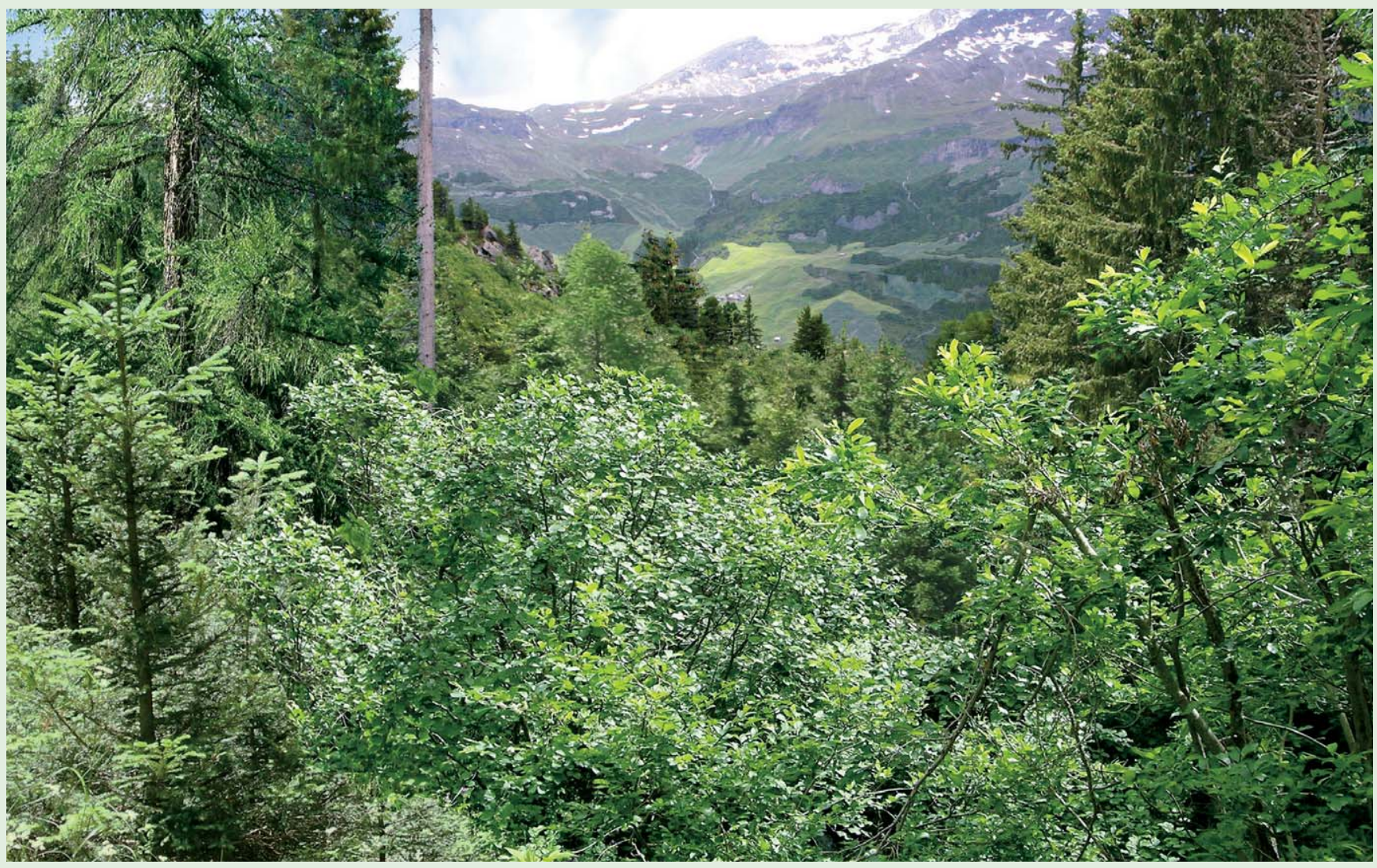

FIGURE 5 Agricultural Liberalization showing an advanced stage of vegetational succession. 
TABLE 1 Assessment of the three BioScene scenarios relating to local sustainability objectives $(\mathrm{BAU}=\mathrm{Business}$ as Usual, LIB $=$ Agricultural Liberalization, BIO = Biodiversity Enhancement). A 5-point scale was used, ranging from ++ for very positive effects to 0 for no effects and - - for very negative effects. Objectives in italics were suggested by local stakeholders, the others by the researchers. (Adapted and translated from Soliva 2007)

\begin{tabular}{|c|c|c|c|c|}
\hline $\begin{array}{l}\text { Sustainability } \\
\text { category }\end{array}$ & Sustainability objectives & BAU & LIB & BIO \\
\hline \multirow{3}{*}{ Biodiversity } & Manage and conserve a variety of farm animal races & + & -- & ++ \\
\hline & $\begin{array}{l}\text { Conserve ecologically viable populations of individual species that are sen- } \\
\text { sitive to agricultural decline }\end{array}$ & $+/-$ & -- & ++ \\
\hline & Create and conserve a highly structured landscape mosaic & $+/-$ & - & ++ \\
\hline \multirow{3}{*}{$\begin{array}{l}\text { Sustainable } \\
\text { natural } \\
\text { resource } \\
\text { management }\end{array}$} & $\begin{array}{l}\text { Increase the quantity of water in rivers and streams used for power produc- } \\
\text { tion }\end{array}$ & 0 & 0 & 0 \\
\hline & $\begin{array}{l}\text { Promote the processing of locally harvested wood and the use of wood for } \\
\text { heating }\end{array}$ & - & -- & 0 \\
\hline & $\begin{array}{l}\text { Manage and take care of forests so as to ensure their protective function } \\
\text { in times of increasing natural hazards (due to global warming) }\end{array}$ & 0 & -- & 0 \\
\hline \multirow{6}{*}{$\begin{array}{l}\text { Rural } \\
\text { development }\end{array}$} & Increase solidarity and cooperation between tourism and agriculture & $+?$ & - & $+?$ \\
\hline & $\begin{array}{l}\text { Make the area more attractive for residents and newcomers (especially for } \\
\text { young people and families) and promote balanced regional development }\end{array}$ & $+/-$ & -- & $+/-$ \\
\hline & $\begin{array}{l}\text { Promote a development strategy guided by the region's own traditions and } \\
\text { values, rather than copying foreign strategies; "to find our own way" }\end{array}$ & 0 & - & -- \\
\hline & $\begin{array}{l}\text { Mitigate the negative effects (noise, pollution, accidents) of the Julier road } \\
\text { (the main road crossing the valley) }\end{array}$ & 0 & 0 & 0 \\
\hline & $\begin{array}{l}\text { Preserve seasonal alpine settlements ("Maiensässe") as constitutive land- } \\
\text { scape elements and part of the cultural heritage }\end{array}$ & $+/-$ & -- & $+?$ \\
\hline & Promote organic farming & + & -- & ++ \\
\hline \multirow{3}{*}{$\begin{array}{l}\text { Social } \\
\text { development }\end{array}$} & Ensure the continuation of family-based farms & - & -- & -- \\
\hline & Promote the use of the local Rhaeto-Romanic language & 0 & - & 0 \\
\hline & $\begin{array}{l}\text { Ensure the continuation of the regional hospital and of schools and public } \\
\text { services }\end{array}$ & 0 & - & 0 \\
\hline \multirow{3}{*}{$\begin{array}{l}\text { Economic } \\
\text { development }\end{array}$} & Ensure sound and sustainable development of tourism & 0 & $-?$ & $+?$ \\
\hline & Promote small enterprises with training facilities & 0 & $-?$ & 0 \\
\hline & Improve the marketing of regional products & + & -- & $+?$ \\
\hline \multirow{2}{*}{$\begin{array}{l}\text { Institutional } \\
\text { capacity for } \\
\text { sustainable } \\
\text { development }\end{array}$} & Establish the regional park "Parc Ela" & + & - & + \\
\hline & $\begin{array}{l}\text { Merge several or all municipalities in the valley and promote cooperation } \\
\text { between villages (eg by creating working groups) }\end{array}$ & 0 & + & 0 \\
\hline
\end{tabular}

\section{Sustainability assessment of the scenarios}

The stakeholders and researchers identified 20 sustainability objectives for the Surses, covering 6 aspects of sustainability. The objectives printed in italics in Table 1 were suggested and assigned to the sustainability categories by stakeholders in a brainstorming exercise, while the other objectives were identified by the researchers, based on their expert knowledge of the area. The objectives were checked for compatibility with national 
and international sustainability objectives, and potential trade-offs were identified.

For the sustainability assessment of the scenarios, only the 4 most relevant drivers (general direct payments, ecological direct payments, agricultural income from conventional products, and agro-environmental regulations) were considered. For each scenario, the key drivers were assessed by the researchers against the sustainability objectives. The results were aggregated into a matrix and then discussed in a deliberative stakeholder meeting. Table 1 shows the aggregated impacts of the scenarios on the sustainability objectives, taking into account stakeholders' views.

The assessment revealed that the $B A U$ scenario had only a minor impact with regard to sustainability objectives, and that it cannot guarantee sustainable development. It was, however, the preferred scenario of most stakeholders, as it was seen to represent continuity and security. It became clear that most stakeholders were satisfied with the current state of their region and did not wish for any drastic changes. In particular, they wanted development that takes local values and traditions into account.

The LIB scenario, on the other hand, was assessed negatively both by the researchers and the stakeholders. The latter rated the landscape visualizations of this scenario only slightly negatively, but they viewed the social, economic, and environmental consequences as unacceptable. Some stakeholders feared that, in a liberalization scenario, the Surses would be practically uninhabitable due to a lack of jobs and public services, and increased risk of natural hazards resulting from the abandonment of most agricultural land. All stakeholders agreed that, in this scenario, the Surses would no longer be attractive to residents or tourists.

The BIO scenario was assessed ambiguously. Without doubt it was the best scenario for biodiversity-related objectives, and its landscape visualizations were rated most positively of all. Some of the associated cultural and social consequences, however, were rejected by many stakeholders. To them, a landscape that is mainly used and maintained for biodiversity conservation is something artificial, and they were convinced that visitors, who look for authenticity, would not appreciate such a landscape. In particular, they did not like the idea of (mainly city-based) conservation organizations managing part of the land, instead of local farmers. Similarly, they disliked the stricter agro-environmental regulations issued outside their region which this scenario would entail.

\section{Recommendations based on stakeholders" views}

Stakeholders found food-producing agriculture, based on local farms, to be crucial for the viability of rural communities in the Surses. It was thus important to them that direct payments to agriculture be maintained. On the other hand, they regret dependence on the federal government. Regionalization of the direct payments system-which has already been suggested by other authors-might increase the acceptance of agricultural policy. Furthermore, stakeholders emphasized the cooperation and mutual solidarity between tourism and agriculture. Specific measures suggested by the stakeholder group include promotion of goat-keeping and traditional breeds of cows and other animals, for whose products they saw an increasing market potential.

While these recommendations may be of limited validity for other mountain areas, the methodological framework presented in the present article-a participatory sustainability assessment of future scenarios-can be applied in other areas. The combination of "bottom-up" and "top-down" procedures proved to be efficient and was accepted by the people involved. Last but not least, the project provided "food for thought" to local stakeholders and helped them picture potential future developments, and it succeeded in bringing researchers and local stakeholders together to jointly think about sustainable futures and how these might be reached. After all, adopting policies that take into account local people's values and needs while helping to maintain landscapes in which people feel at home is a prerequisite for mitigating outmigration of peripheral areas in the Swiss Alps.

\author{
"We are already allowing \\ the wolf and the lynx to \\ return, and soon the bear. \\ But at some point we will \\ have to say that we're no \\ longer at home in this \\ wilderness." (Stakeholder \\ commenting on the liberal- \\ ization scenario)
}

\section{ACKNOWLEDGMENTS}

The author would like to thank all the stakeholders for their collaboration; Dr. Marcel Hunziker and Dr. Janine Bolliger, WSL, for their collaboration in the BioScene project; and Prof. Dr. Maria Partidário, Dr. Olivia Bina, and Dr. William Sheate for conceptual work regarding sustainability assessment.

\section{AUTHOR}

Reto Soliva

Swiss Federal Research Institute WSL, Social Sciences in Landscape Research Group, Zürcherstrasse 111 8903 Birmensdorf, Switzerland. reto.soliva@wsl.ch

Reto Soliva is a geographer and researcher at the Swiss Federal Research Institute WSL. He conducts research on landscape change, agricultural decline, biodiversity, mountain areas, and protected areas.

\section{FURTHER READING}

Bauer N. 2005. Für und wider Wildnis-soziale Dimensionen einer aktuellen gesellschaftlichen Debatte. Zurich and Berne, Switzerland: Bristol-Stiftung and Haupt.

Gibson RB, Hassan S, Holtz S, Tansey J, Whitelaw G. 2005. Sustainability Assessment. Criteria, Processes and Applications. London, United Kingdom: Earthscan.

Hunziker M. 1995. The spontaneous reafforestation in abandoned agricultural lands: Perception and aesthetical assessment by locals and tourists. Landscape and Urban Planning 31:399-410.

Soliva R. 2007. Die Zukunft des Schweizer Berggebiets: Eine partizipative Nachhaltigkeitsprüfung von Landwirtschafts- und Landschaftsszenarios. GAIA 16(2):128-136. 